THE KURUME MEDICAL JOURNAL Vol. 9, No. 1, 1962

\title{
EXPERIMENTAL STUDIES ON EXCESSIVE INTAKE OF $\mathrm{NaCl}$ \\ I. THE EFFECT OF SALT WATER INTAKE ON THE GROWTH OF RAT
}

TAKEO OKANO, HIROJI ESAKI, YOSHIMARO MIYAZAKI, TAKUSHI FUJITA AND HIDEO OGISHIMA

Department of Hygiene and Public Health*, Kurume University School of Medicine, Kurume-city, Japan

\section{INTRODUCTION}

$\mathrm{NaCl}$ is an indispensable substance for human beings, but variation in the amount of intake causes ill health. In the field of pharmacology, it is classified as one of the denaturating substances. In medical literature it states that $\mathrm{NaCl}$ intake to an excess causes inflammation on the gastric wall, the symptoms being pain and vomiting, and further by a higher degree of stimulation, death due to shock might occur. The lethaldose for a human is $5-10 \mathrm{~g}$. per $1 \mathrm{~kg}$.

Sato et al. (1959) ${ }^{15)}$ reported that feeding a mouse with ordinary Japanese food containing salt causes bleeding on the mucous membrane of the stomach. Sasaki $(1956)^{1112)}$ recognized the significant correlation between the $\mathrm{NaCl}$ intake and mortality of cerebral hemorrhage, and for the prevention of the hypertonic diseases, he pointed out the necessity for care in regulating $\mathrm{NaCl}$ intake ${ }^{13)}$. However, Kimura $(1960)^{5)}$ did not recognize any relationship between blood pressure and the amount of $\mathrm{NaCl}$ intake. In addition, there are reports on favorite taste in salt ${ }^{3}$, the relationship between the $\mathrm{NaCl}$ intake and Vitamin $\mathrm{C}^{134)}$ and many reports on the correlation of high blood pressure and arteriosclerosis ${ }^{6 / 8)(10)(4) 16)}$. At the same time, one of the authors, Miyazaki $(1961)^{9}$, made an epidemiological survey on the blood pressure of farmers in Miyaki County of Saga Prefecture and observed a meaningful correlation between the morbidity of hypertension and the amount of $\mathrm{NaCl}$ intake. The authors also felt certain that there are many problems to clarify experimentally as to the effect of $\mathrm{NaCl}$ intake.

In this paper, a report is made on the effect of salt water intake in various concentrations on the growth of rats during their maturation period.

\section{EXPERIMENTAL METHOD}

\section{1) Animal}

The rats used for the experiment were Rattus norvegius var. albinus (Hatai), albino rat. Among reproduced rats from a pair of Wister-King A originally re-

* Director : Prof. T. Okano, M. D. 
ceived from National Institute of Heredity and the animal room of Kyushu University Medical School, the authors selected ones from the same litter, healthy, pure and with definite date of birth.

\section{2) The method of raising in a constant humidity and temperature room}

The animals were raised in a specially designed room of constant temperature, $21 \pm 1^{\circ} \mathrm{C}$, and humidity, $60 \pm 5 \%$. The temperature and humidity were automatically recorded by an automatic thermometer and hygrometer (made by Shimazu Seisakusyo) and the average value for every 6 days was recorded in dry and wet bulb temperature. Oriental Solid Food NMF (for reproduction) was administered.

3) The method of salt water administration

The salt was dissolved (the first class quality chemical) in concentrations of $1 \%, 2 \%$ and $3 \%$ in the city well water. The salt water was given to rats in bottles with measurement in the condition that those rats could drink it freely any time. The remainder in each bottle was accurately measured and the amount of salt water intake was recorded every day as well as the average for 6 days which was calculated and added to the record. Administration was begun in one group on the 60th day after birth (the latter part of puberty) and in another group on the 120th day (the early part of the growth completion). 16 male and female rats from 2 litters were separated to 4 groups, including one control group.

\section{4) Others}

As to determining the amount of food intake, the measurement of body weight and the length of the tail, the authors followed Fujita's method ${ }^{2)}$ of the same department.

\section{EXPERIMENTAL RESULT}

I The group in which the start of administration was at the latter part of puberty (the 60th day after birth)

Eight rats from one litter (4 male and 4 female), born on May 1, 1960 were classified according to the following groups, and the administration was started on the 60th day after birth :

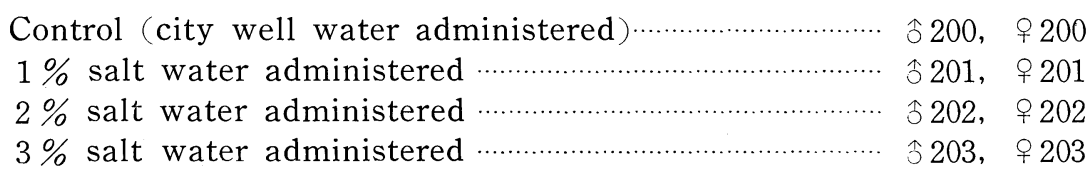

Figures $1(\hat{j})$ and $2($ o $)$ show the summarized result, comparing the control in body weight, length of the tail, the amount of food intake, the amount of salt water taken and also the variations of humidity or temperature in the animal room.

In the symbol used for female rats " ${ }_{\mathrm{M}} \mathrm{Y}_{\mathrm{N}}$ ", $\mathrm{Y}$ stands for young breeding, $\mathrm{M}$ for the number of delivered younglings and $\mathrm{N}$ for the number of the alive.

In comparison with the control, the three groups which took the salt water showed less growth both in body weight and the length of the tail. The rate of growth varied inversely as the percentage of salt concentration increased the administration of $3 \%$ salt water, especially, caused rapid decrease in weight in both male ( $\$ 203$ ) and female ( $q 203$ ). The male died on the 36 th day and the female on 
Figure 1. The growth of rats when administered the salt water, the experiment starting the latter part of puberty (the 60 th day after birth) ( $\hat{o}$ )
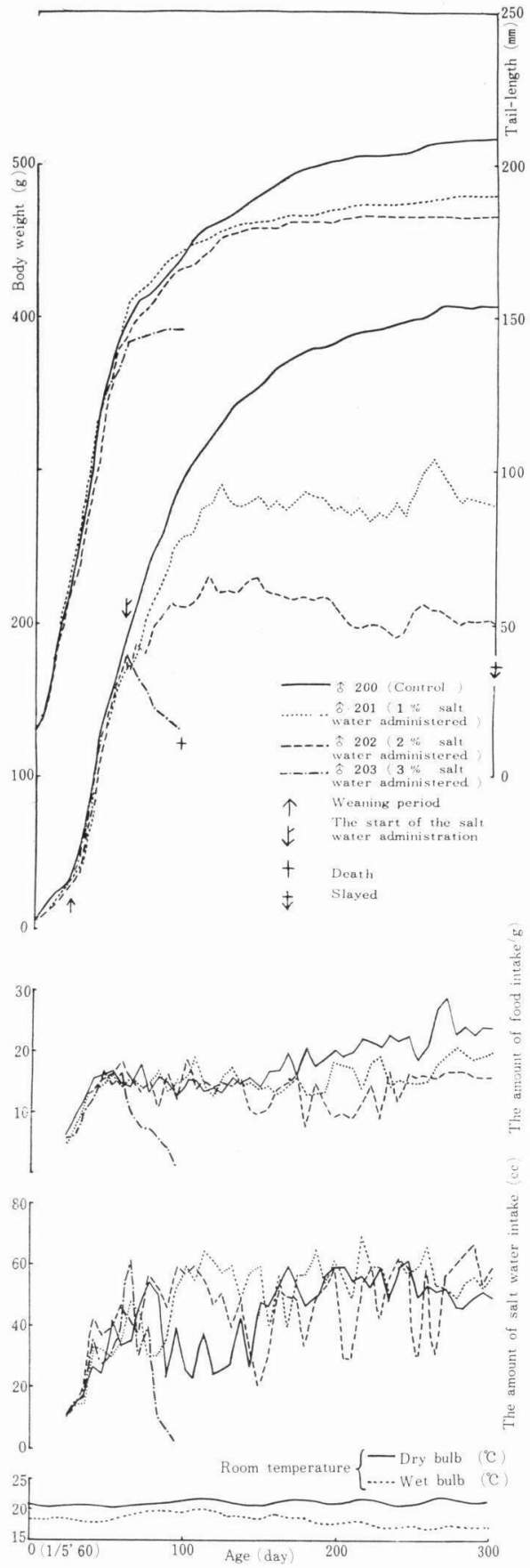

Figure 2. The growth of rats when administered the salt water, the experiment starting the latter part of puberty (the 60 th day after birth) (q)

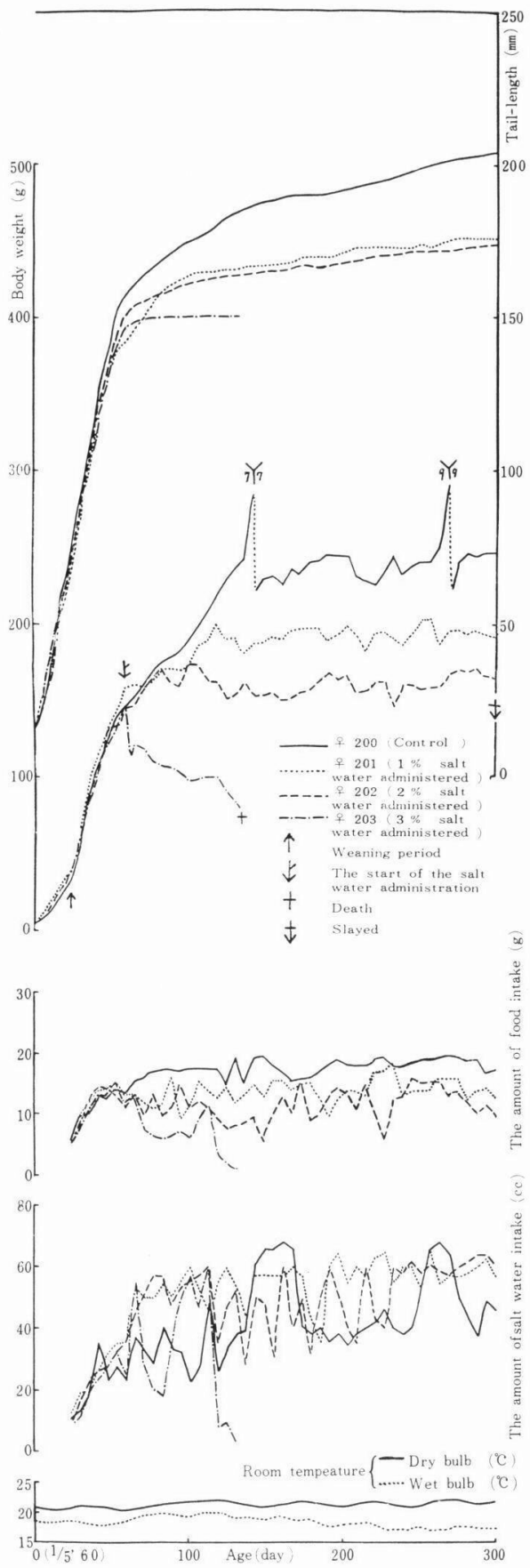


the 72 nd day.

II The group in which the start of administration was at the early part of growth completion (the 120th day after birth)

Eight rats from one litter (4 male and 4 female) born on May 30, 1960 were classified to the following groups, and the administration was started on the 120th day after birth :

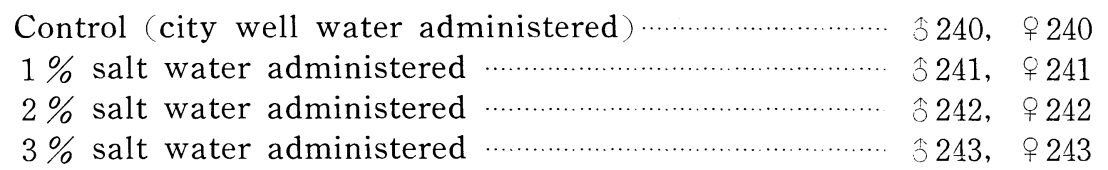

Figures $3(\hat{3})$ and 4 ( $(9)$ show the summarized results, comparing the control in body weight, length of the tail, the amount of food intake, the amount of salt water taken and also the variations of temperature or humidity in the animal room. In comparison with the control, the three groups which took the salt water showed less growth both in body weight and length of tail. The rate of growth varied inversely as the percentage of salt concentration increased; the administration of $3 \%$ salt water particularly, causing a rapid decrease both in male (\$243) and female ( 9243 ). The male died on the 97th day and the female on the 123rd day.

\section{Comparative Discussion as to the Starting Feriod of the Experiment}

A comparative discussion was made concerning the onset of the experiment between the latter part of puberty (abbreviated as LPP) and the early part of growth completion (abbreviated as EGC). The authors observed the difference in body weight, length of the tail, the amount of food intake and the amount of total salt intake. (See Table 1-4)

(1) Body Weight

Considering the body weight of both male and female control rats on the 180th day as 100 , the following results were observed:

\begin{tabular}{|c|c|}
\hline LPP & $1 \%$ salt water administered \\
\hline Lit & $2 \%$ salt water administered \\
\hline
\end{tabular}

Generally speaking, male rats grew less than female rats. On the other hand:

$\begin{array}{lll}\text { EGC } & 1 \% \text { salt water administered } & \$ 91 \\ & 2 \% \text { salt water administered } & \$ 86 \\ & \$ 81 \\ & \$ 73\end{array}$

Contrary to LPP, female rats grew less than the male rats in EGC. From these results, we can tell that LPP is more affected by the administration of salt water than EGC, the growth in body weight being less. At the administration of $3 \%$ salt water, the male in LPP died on the 36 th day (the decreasing rate compared with the body weight at the start of the experiment was $27.8 \%$ ) and female on the 72 nd day (the decreasing rate compared with the body weight at the start of the experiment was $44.8 \%$ ). The male in EGC died on the 97 th day $(59.6 \%$ ) and female on the $123 \mathrm{rd}$ day $(51.8 \%)$. Those in LPP died earlier than EGC, and it was confirmed that LPP was more affected by the salt water 
Figure 3. The growth of rats when administered the salt water, the experiment atarting the early part of growth completion (the 120th day after birth)( $\hat{o})$.

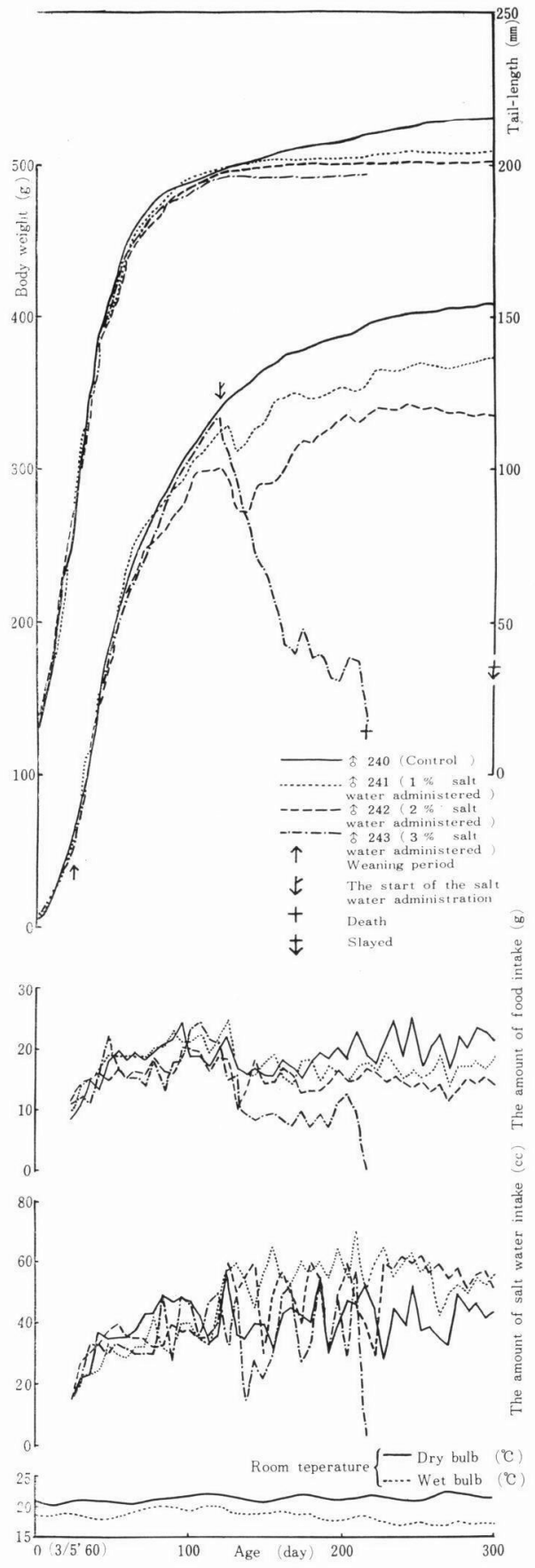

Figure 4. The growth of rats when administered the salt water, the experiment starting the early part of growth completion (the 120th day after birth) (q).

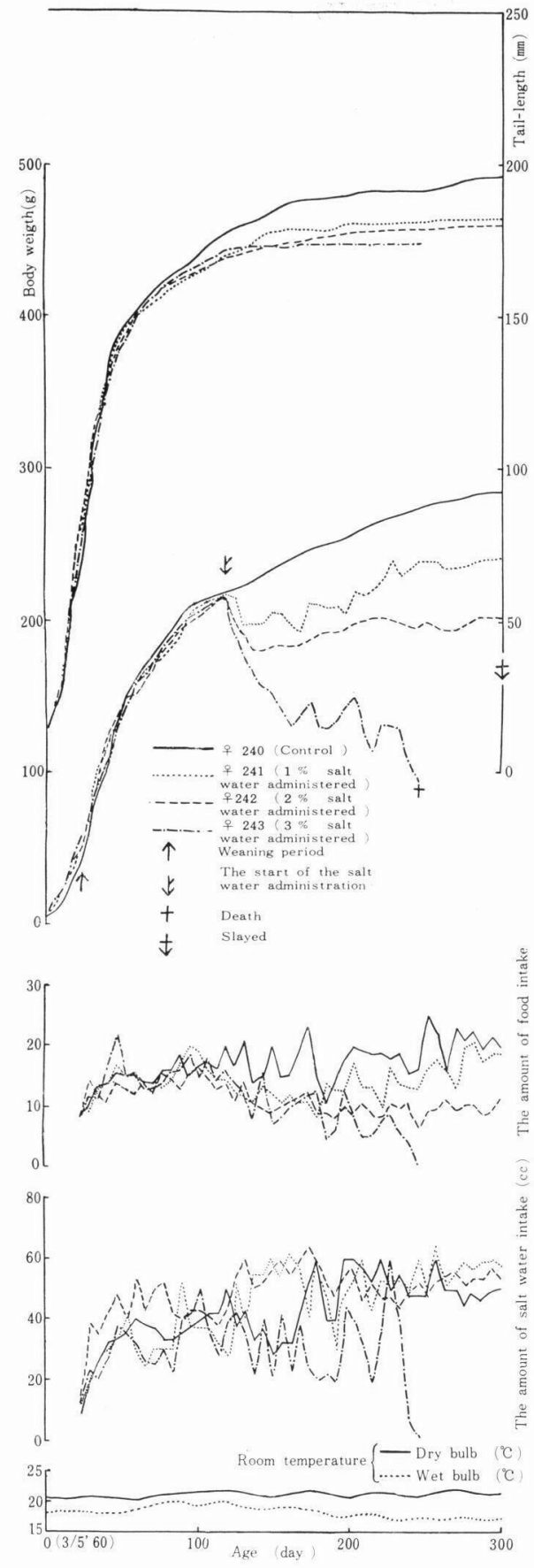


TABLE 1

The growth in body weight of rats (the experiment starting at different stage)

\begin{tabular}{|c|c|c|c|c|c|c|c|c|c|c|c|c|c|c|c|c|c|c|c|c|c|c|}
\hline \multirow{2}{*}{$\begin{array}{l}\text { Starting } \\
\text { period of the } \\
\text { experiment }\end{array}$} & \multirow{2}{*}{ Sex } & \multirow{2}{*}{$\begin{array}{l}\text { The days } \\
\text { Concentration } \\
\text { of salt water }\end{array}$} & \multicolumn{4}{|c|}{$\begin{array}{l}\text { The starting day } \\
\text { of the experiment }\end{array}$} & \multicolumn{4}{|c|}{ The 60th day } & \multicolumn{4}{|c|}{ The 120th day } & \multicolumn{4}{|c|}{ The 180th day } & \multicolumn{4}{|c|}{ The 240th day } \\
\hline & & & Control & $1 \%$ & $2 \%$ & $3 \%$ & Control & $1 \%$ & $2 \%$ & $3 \%$ & Control & $11 \%$ & $2 \%$ & $3 \%$ & Control & $11 \%$ & $2 \%$ & $3 \%$ & Control & $11 \%$ & $62 \%$ & $3 \%$ \\
\hline \multirow{4}{*}{$\begin{array}{l}\text { The group in } \\
\text { which the } \\
\text { start of admi- } \\
\text { nistration was } \\
\text { at the latter } \\
\text { part of puber- } \\
\text { ty(the 60th day } \\
\text { after birth) }\end{array}$} & \multirow{2}{*}{$\hat{o}$} & $\begin{array}{c}\text { Body } \\
(\mathrm{g})\end{array}$ & 190 & 171 & 181 & 180 & 331 & 291 & 221 & 130 & 381 & 283 & 215 & - & 398 & 271 & 195 & - & 408 & 278 & $8 \quad 200$ & - \\
\hline & & $\begin{array}{l}\text { Comparison } \\
\text { with the } \\
\text { control }(100)\end{array}$ & 100 & 90 & 95 & 95 & 100 & 88 & 67 & $\begin{array}{r}(1) \\
44\end{array}$ & 100 & 74 & 56 & - & 100 & 68 & 49 & - & 100 & 68 & \begin{tabular}{l|l|}
8 & 49
\end{tabular} & - \\
\hline & \multirow{2}{*}{$q$} & $\begin{array}{c}\text { Body weight } \\
(\mathrm{g})\end{array}$ & 150 & 158 & 145 & 145 & 218 & 200 & 162 & 111 & 240 & 197 & 156 & 80 & 232 & 186 & 160 & - & 246 & 192 & 2164 & - \\
\hline & & $\begin{array}{l}\text { Comparison } \\
\text { with the } \\
\text { control }(100)\end{array}$ & 100 & 105 & 97 & 97 & 100 & 91 & 74 & 51 & 100 & 82 & 65 & $\begin{array}{r}(2) \\
34 \\
\end{array}$ & 100 & 80 & 69 & - & 100 & 78 & 67 & - \\
\hline \multirow{4}{*}{$\begin{array}{l}\text { The group in } \\
\text { which the start } \\
\text { of administra- } \\
\text { tion was at } \\
\text { the early part } \\
\text { of growth } \\
\text { completion } \\
\text { (the 120th day } \\
\text { after birth) }\end{array}$} & \multirow{2}{*}{ of } & $\begin{array}{c}\text { Body weight } \\
(\mathrm{g})\end{array}$ & 340 & 326 & 306 & 334 & 380 & 346 & 316 & 176 & 402 & 366 & 342 & 135 & 408 & 372 & 335 & - & & & & \\
\hline & & $\begin{array}{l}\text { Comparison } \\
\text { with the } \\
\text { control (100) }\end{array}$ & 100 & 96 & 90 & 98 & 100 & 91 & 83 & 46 & 100 & 91 & 85 & \begin{tabular}{|r|}
$(3)$ \\
34 \\
\end{tabular} & 100 & 91 & 81 & - & & & & \\
\hline & \multirow[t]{2}{*}{ o } & 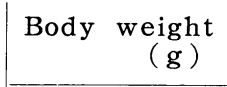 & 220 & 216 & 214 & 197 & 250 & 212 & 190 & 132 & 274 & 235 & 196 & 106 & 281 & 242 & 202 & 95 & & & & \\
\hline & & $\begin{array}{l}\text { Comparison } \\
\text { with the } \\
\text { control }(100)\end{array}$ & 100 & 98 & 97 & 90 & 100 & 85 & 76 & 53 & 3 & 86 & 83 & 39 & 100 & 86 & 73 & $\begin{array}{r}(4) \\
35 \\
\end{array}$ & & & & \\
\hline
\end{tabular}

Remarks :

1) The compared ratio with the control $295 \mathrm{~g}$ on the $96 \mathrm{th}$ day in body weight at the time of death.

2) The compared ratio with the control $236 \mathrm{~g}$ on the 132nd day in the same as 1).

3) The compared ratio with the control $392 \mathrm{~g}$ on the 217 th day in the same as 1).

4) The compared ratio with the control $275 \mathrm{~g}$ on the $243 \mathrm{rd}$ day in the same as 1 ). 
TABLE 2

The growth in tail-length of rats (the experiment starting at different stage)

\begin{tabular}{|c|c|c|c|c|c|c|c|c|c|c|c|c|c|c|c|c|c|c|c|c|c|c|}
\hline \multirow{2}{*}{$\begin{array}{l}\text { Starting } \\
\text { period of the } \\
\text { experiment }\end{array}$} & \multirow{2}{*}{ Sex } & \multirow{2}{*}{$\begin{array}{l}\text { The days } \\
\text { Concentration } \\
\text { of salt water }\end{array}$} & \multicolumn{4}{|c|}{$\begin{array}{l}\text { The starting day } \\
\text { of the experiment }\end{array}$} & \multicolumn{4}{|c|}{ The 60th day } & \multicolumn{4}{|c|}{ The 120th day } & \multicolumn{4}{|c|}{ The 180th day } & \multicolumn{4}{|c|}{ The 240th day } \\
\hline & & & Control & $1 \%$ & $2 \%$ & $3 \%$ & Control & $11 \%$ & $2 \%$ & $3 \%$ & Control & $1 \%$ & $2 \%$ & $3 \%$ & Conirol & $1 \%$ & $2 \%$ & $63 \%$ & Control & $11 \%$ & $2 \%$ & $3 \%$ \\
\hline \multirow{4}{*}{$\begin{array}{l}\text { The group in } \\
\text { which the start } \\
\text { of administra- } \\
\text { tion was at } \\
\text { the latter part } \\
\text { of puberty } \\
\text { (the 60th day } \\
\text { after birth) }\end{array}$} & \multirow{2}{*}{$\hat{o}$} & $\underset{(\mathrm{cm})}{\text { Tail-length }}$ & 14.9 & 15.5 & 14.4 & 14.2 & 18.1 & 17.8 & 17.6 & 14.6 & 19.9 & 18.3 & 18.1 & - & 20.3 & 18.7 & 18.3 & $3-$ & 20.9 & 19.0 & 18.3 & $3-$ \\
\hline & & $\begin{array}{l}\text { Comparison } \\
\text { with the } \\
\text { control }(100)\end{array}$ & 100 & 104 & 97 & 95 & 100 & 98 & 97 & $\begin{array}{r}(1) \\
86\end{array}$ & 100 & 92 & 91 & - & 100 & 92 & 90 & - & 100 & 91 & 88 & $8-$ \\
\hline & \multirow{2}{*}{ 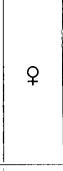 } & $\begin{array}{r}\text { Tail-length } \\
(\mathrm{cm})\end{array}$ & 15.6 & 14.2 & 15.0 & 14.7 & 18.2 & 16.5 & 16.3 & 15.0 & 19.0 & 17.0 & 16.7 & 715.0 & 19.7 & 17.3 & 17.1 & $1-$ & 20.4 & 17.6 & $617 \cdot 4$ & $4-$ \\
\hline & & $\begin{array}{l}\text { Comparison } \\
\text { with the } \\
\text { control (100) }\end{array}$ & 100 & $9 \mathrm{I}$ & 96 & 94 & 100 & 91 & 90 & 82 & 100 & 89 & 88 & $\begin{array}{r}(2) \\
81\end{array}$ & 100 & 88 & 87 & $7-$ & 100 & 86 & \begin{tabular}{l|l|}
6 & 85
\end{tabular} & $5-$ \\
\hline \multirow{4}{*}{$\begin{array}{l}\text { The group in } \\
\text { which the start } \\
\text { of administra- } \\
\text { tion was at } \\
\text { the early part } \\
\text { of growth } \\
\text { completion } \\
\text { (the 120th day } \\
\text { after birth) }\end{array}$} & \multirow{2}{*}{$\hat{o}$} & $\begin{array}{r}\text { Tail-length } \\
(\mathrm{cm})\end{array}$ & 19.7 & 19.9 & 19.7 & 19.6 & 20.6 & 20.2 & 20.0 & 19.6 & 21.2 & 20.4 & 20.1 & 19.7 & 21.5 & 20.4 & 20.1 & $1-$ & & & & \\
\hline & & $\begin{array}{l}\text { Comparison } \\
\text { with the } \\
\text { control }(100)\end{array}$ & 100 & 101 & 100 & 99 & 100 & 98 & 97 & 95 & 100 & 96 & 95 & $\mid \begin{array}{r}(3) \\
94\end{array}$ & 100 & 95 & 93 & $3-$ & & & & \\
\hline & & Tail-length & 17.8 & 17.0 & 16.9 & 17.2 & 18.9 & 17.9 & $|17.6| 1$ & 17.4 & 19.1 & 18.1 & 17.9 & 917.4 & 19.6 & 18.2 & 18.0 & 17.4 & & & & \\
\hline & & $\begin{array}{l}\text { Comparison } \\
\text { with the } \\
\text { control }(100)\end{array}$ & 100 & 96 & 95 & 97 & 100 & 95 & 93 & \begin{tabular}{l|l}
3 & 92
\end{tabular} & 100 & 95 & 94 & $4 \mid$\begin{tabular}{l|}
4 \\
4.
\end{tabular} & 100 & 93 & 92 & $\begin{array}{r}(4) \\
91 \\
\end{array}$ & & & & \\
\hline
\end{tabular}

Remarks :

1) The compared ratio with the control $17.0 \mathrm{~cm}$ on the $96 \mathrm{th}$ day in tail-length at the time of death.

2) The compared ratio with the control $18.5 \mathrm{~cm}$ on the $132 \mathrm{nd}$ day as in the 1).

3) The compared ratio with the control $21.0 \mathrm{~cm}$ on the $217 \mathrm{th}$ day as in the 1).

4) The compared ratio with the control $19.2 \mathrm{~cm}$ on the $243 \mathrm{rd}$ day as in the 1 ). 
TABLE 3

The food intake of rats (the experiment starting at different stage)

(The averaged amount per a rat per day for 6 days)

\begin{tabular}{|c|c|c|c|c|c|c|c|c|c|c|c|c|c|c|c|c|c|c|c|c|c|c|}
\hline \multirow{2}{*}{$\begin{array}{l}\text { Starting period } \\
\text { of the } \\
\text { experiment }\end{array}$} & \multirow{2}{*}{ Sex } & \multirow{2}{*}{\begin{tabular}{l}
\multicolumn{1}{c}{ The days } \\
Concentration \\
of salt water
\end{tabular}} & \multicolumn{4}{|c|}{$\begin{array}{l}\text { The starting day } \\
\text { of the experiment }\end{array}$} & \multicolumn{4}{|c|}{ The 60th day } & \multicolumn{4}{|c|}{ The 120th day } & \multicolumn{4}{|c|}{ The 180th day } & \multicolumn{4}{|c|}{ The 240th day } \\
\hline & & & Control & $11 \%$ & $2 \%$ & $3 \%$ & Control & $1 \mid 1 \%$ & $2 \%$ & $3 \%$ & Control & $1 \%$ & $2 \%$ & $3 \%$ & Control & $1 \%$ & $2 \%$ & $3 \%$ & Control & $1 \%$ & $2 \%$ & $3 \%$ \\
\hline \multirow{8}{*}{$\begin{array}{l}\text { The group in } \\
\text { which the } \\
\text { start of admi- } \\
\text { nistration was } \\
\text { at the latter } \\
\text { part of puberty } \\
\text { (the 60th day } \\
\text { after birth) }\end{array}$} & \multirow{4}{*}{$\hat{o}$} & $\begin{array}{l}\text { The amount } \\
\text { of intake }(g)\end{array}$ & 15.0 & 14.6 & 18.5 & 16.5 & 14.0 & 13.3 & 14.3 & \begin{tabular}{|l|}
$(1)$ \\
4.5 \\
\end{tabular} & 20.7 & 13.0 & 8.2 & - & 22.2 & 15.6 & 12.5 & - & 24.0 & 20.0 & 16.0 & - \\
\hline & & Calory $/ \mathrm{kg}$ & 283 & 307 & 367 & 329 & 152 & 164 & 232 & 124 & 196 & 165 & $|137|$ & - & 200 & 207 & 230 & - & 211 & 258 & 287 & - \\
\hline & & $\begin{array}{c}\mathrm{N} \text { amount } \\
(\mathrm{g} / \mathrm{kg})\end{array}$ & 3.31 & 3.58 & 4.28 & 3.84 & 1.77 & 1.91 & 2.71 & 1.45 & 2.28 & 1.92 & 1.60 & - & 2.34 & 2.41 & 2.69 & - & 2.46 & $3.013^{3}$ & 3.35 & - \\
\hline & & $\begin{array}{c}\text { The amount of } \\
\text { salt intake } \\
(\mathrm{g} / \mathrm{kg})\end{array}$ & 0.51 & 0.56 & 0.66 & 0.60 & 0.28 & 0.30 & 0.37 & 0.22 & 0.35 & 0.30 & 0.25 & - & 0.36 & 0.37 & 0.42 & - & 0.38 & $0.47 \mathrm{C}$ & 0.52 & - \\
\hline & \multirow{4}{*}{ 우 } & $\begin{array}{l}\text { The amount } \\
\text { of intake }(g)\end{array}$ & 13.5 & $|12.8|$ & 11.31 & 11.2 & 17.5 & $\mid 12.7$ & 9.0 & 3.6 & 15.8 & 15.38 & 8.8 & $\left|\begin{array}{c}(2) \\
2.0\end{array}\right|$ & 18.2 & 13.2 & 12.8 & - & 17.2 & 13.09 & 9.5 & - \\
\hline & & Calory/kg & 323 & 291 & 280 & 277 & 288 & 228 & $|199|$ & $|116|$ & 237 & 280 & | $203 \mid$ & 90 & 282 & 255 & $\mid 287$ & - & 251 & 243 & 208 & - \\
\hline & & $\begin{array}{c}\mathrm{N} \text { amount } \\
(\mathrm{g} / \mathrm{kg})\end{array}$ & 3.77 & 3.393 & $\left.3.27\right|^{3}$ & $|3.24|$ & 3.36 & 2.66 & 2.33 & 1.36 & 2.76 & $\left.3.25\right|_{2} ^{2}$ & 2.36 & 1.05 & 3.29 & 2.97 & $3.35 \mid$ & - & 2.93 & $\left.2.84\right|^{2}$ & 2.43 & - \\
\hline & & 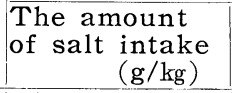 & 0.58 & 0.53 & $0.51 \mathrm{C}$ & 0.50 & 0.52 & 0.41 & 0.36 & 0.21 & 0.43 & $0.51 \mathrm{C}$ & 0.37 & 0.16 & 0.51 & 0.46 & 0.52 & - & 0.45 & 0.440 & 0.38 & - \\
\hline \multirow{8}{*}{$\begin{array}{l}\text { The group in } \\
\text { which the } \\
\text { start of admi- } \\
\text { nistration was } \\
\text { at the early } \\
\text { part of growth } \\
\text { completion } \\
\text { (the 120th day } \\
\text { after birth) }\end{array}$} & \multirow{4}{*}{$\hat{o}$} & $\begin{array}{l}\text { The amount } \\
\text { of intake }(g)\end{array}$ & 20.0 & 22.1 & 19. 2 & 21.7 & 18. 0 & 18.7 & 13. $7^{\prime}$ & 6.9 & 19. 0 & 15.0 & 15.0 & $\left|\begin{array}{r}(3) \\
3.3\end{array}\right|$ & 21.5 & 19.0 & 14.5 & - & & & & \\
\hline & & Calory $/ \mathrm{kg}$ & 211 & 243 & 230 & $|233|$ & 171 & 195 & 156 & $|141|$ & 170 & 147 & 157 & 88 & 189 & 183 & $|155|$ & - & & & & \\
\hline & & $\begin{array}{c}N \text { a mount } \\
(\mathrm{g} / \mathrm{kg})\end{array}$ & 2. 46 & 2.84 & 2.68 & 2.72 & 1.98 & 2.27 & 1.82 & $|1.64|$ & 1.98 & $|1.72|$ & 1.84 & 1.02 & 2. 21 & 2. 14 & 1.81 & - & & & & \\
\hline & & $\begin{array}{r}\text { The amount } \\
\text { of salt intake } \\
(\mathrm{g} / \mathrm{kg})\end{array}$ & 0.38 & 0.44 & 0.42 & 0.42 & 0.31 & 0.35 & 0.28 & 0.26 & 0.31 & $0.27 \mid$ & 0.28 & 0.16 & 0.34 & 0.33 & 0.28 & - & & & & \\
\hline & \multirow{4}{*}{ ㅇ } & $\begin{array}{l}\text { The amount } \\
\text { of intake }(g)\end{array}$ & 19. 8 & 14.6 & 13.9 & 15.8 & 15.5 & 11.3 & 9.0 & 8.0 & 15.7 & 13.5 & 11.0 & 4.3 & 20.0 & 19.0 & 11.5 & $\begin{array}{r}(4) \\
3.0 \\
\end{array}$ & & & & \\
\hline & & Calory $/ \mathrm{kg}$ & 323 & 243 & 233 & 292 & 223 & 192 & 171 & 218 & 206 & 206 & 201 & 146 & 256 & 282 & 204 & 113 & & & & \\
\hline & & $\begin{array}{c}\mathrm{N} \text { amount } \\
(\mathrm{g} / \mathrm{kg})\end{array}$ & 3. 77 & 2.83 & 2.72 & 3.41 & 2.60 & 2.23 & 1.98 & 2.54 & 2. 40 & 2.41 & $|2 \cdot 35|$ & 1.70 & 2.98 & 3.29 & 2.39 & 1.32 & & & & \\
\hline & & $\begin{array}{c}\begin{array}{c}\text { The amount } \\
\text { of salt intake } \\
(\mathrm{g} / \mathrm{kg})\end{array} \\
\end{array}$ & 0.58 & 0.44 & 0.42 & 0.53 & 0.40 & 0.35 & 0.31 & 0.39 & 0.37 & 0.37 & 0.36 & 0.26 & $\therefore 0.46$ & 0.51 & 0.37 & 0.20 & & & & \\
\hline
\end{tabular}

Remarks: 1) The amount of food intake per a rat per day for the 6 days before death (died on the 96 th day. 2 ) The same as 1). (died on the 132nd day). 3) The same as 1). (died on the 217th day). 4) The same as 1). (died on the 243rd day). 
TABLE 4

The total salt intake of rats (the experiment starting at different stage)

(The averaged amount per a rat per day for 6 days)

\begin{tabular}{|c|c|c|c|c|c|c|c|c|c|c|c|c|c|c|}
\hline \multirow[b]{2}{*}{$\begin{array}{l}\text { Starting period } \\
\text { of the experi-S } \\
\text { ment }\end{array}$} & \multirow[b]{2}{*}{ Sex } & \multirow{2}{*}{$\begin{array}{c}\text { Concentration } \\
\text { of salt } \\
\text { water } \\
\text { days }\end{array}$} & \multicolumn{3}{|c|}{ Control } & \multicolumn{3}{|c|}{$\begin{array}{l}1 \% \text { salt water admi- } \\
\text { nistered }\end{array}$} & \multicolumn{3}{|c|}{$\begin{array}{l}2 \% \text { salt water admi- } \\
\text { nistered }\end{array}$} & \multicolumn{3}{|c|}{$\begin{array}{l}3 \% \text { salt water admi- } \\
\text { nistered }\end{array}$} \\
\hline & & & $\begin{array}{l}\text { The } \\
\text { amount } \\
\text { of } \\
\text { water } \\
\text { taken } \\
\quad \text { (cc) }\end{array}$ & $\begin{array}{l}\text { The } \\
\text { salt } \\
\text { intake } \\
\text { from } \\
\text { the } \\
\text { food } \\
\quad(g)\end{array} \mid$ & $\begin{array}{l}\text { The } \\
\text { total } \\
\text { salt } \\
\text { intake } \\
\text { per kg } \\
\quad(\mathrm{g})\end{array} \mid$ & $\begin{array}{l}\text { The } \\
\text { amount } \\
\text { of salt } \\
\text { water } \\
\text { intake } \\
\quad \text { (cc) }\end{array}$ & $\left|\begin{array}{l}\text { The } \\
\text { salt } \\
\text { intake } \\
\text { from } \\
\text { the } \\
\text { food }(g)\end{array}\right|$ & $\left|\begin{array}{l}\text { The } \\
\text { total } \\
\text { salt } \\
\text { !ntake } \\
\text { per } \quad \mathrm{kg} \\
\quad(\mathrm{g})\end{array}\right|$ & $\begin{array}{l}\text { The } \\
\text { amount } \\
\text { of salt } \\
\text { water } \\
\text { intake } \\
\quad \text { (cc) }\end{array}$ & $\begin{array}{l}\text { The } \\
\text { salt } \\
\text { intake } \\
\text { from } \\
\text { the } \\
\text { food }(g)\end{array}$ & $\left|\begin{array}{l}\text { The } \\
\text { total } \\
\text { salt } \\
\text { intake } \\
\text { per } \mathrm{kg} \\
\quad(\mathrm{g})\end{array}\right|$ & $\begin{array}{l}\text { The } \\
\text { amount } \\
\text { of salt } \\
\text { water } \\
\text { intake } \\
\quad \text { (cc) }\end{array}$ & $\begin{array}{l}\text { The } \\
\text { salt } \\
\text { intake } \\
\text { from } \\
\text { the } \\
\text { food }(g)\end{array}$ & $\begin{array}{l}\text { The } \\
\text { total } \\
\text { salt } \\
\text { intake } \\
\text { per } \mathrm{kg} \\
\quad(\mathrm{g})\end{array}$ \\
\hline \multirow{6}{*}{$\begin{array}{l}\text { The group in } \\
\text { which the } \\
\text { start of admi- } \\
\text { nistration was } \\
\text { at the latter } \\
\text { part of } \\
\text { puberty (the } \\
60 t h \text { day after } \\
\text { birth) }\end{array}$} & \multirow{3}{*}{\multicolumn{2}{|c|}{$\begin{array}{l}\text { The starting day } \\
\text { of the experiment } \\
\text { The 60th day } \\
\text { The 120th day } \\
\text { The 180th day } \\
\hat{o} \text { The 240th day } \\
\text { The averaged *** } \\
\text { amount of experi- } \\
\text { mental period }\end{array}$}} & 34 & 0.01 & 0.51 & $35^{*}$ & 0.10 & 0.56 & $47^{*}$ & 0.12 & 0.66 & $39^{*}$ & 0.11 & 0.60 \\
\hline & & & $\begin{array}{l}30 \\
47 \\
55 \\
50 \\
\end{array}$ & $\begin{array}{l}0.09 \\
0.14 \\
0.15 \\
0.16\end{array}$ & $\begin{array}{l}0.27 \\
0.35 \\
0.36 \\
0.38 \\
\end{array}$ & $\begin{array}{l}62 \\
58 \\
62 \\
57\end{array}$ & $\begin{array}{l}0.09 \\
0.09 \\
0.10 \\
0.13\end{array}$ & $\begin{array}{l}2.43 \\
2.35 \\
2.66 \\
2.52 \\
\end{array}$ & $\begin{array}{l}47 \\
33 \\
63 \\
60 \\
\end{array}$ & $\begin{array}{l}0.09 \\
0.05 \\
0.08 \\
0.10 \\
\end{array}$ & $\begin{array}{l}4.63 \\
3.32 \\
6.88 \\
3.50 \\
\end{array}$ & $\begin{array}{l}5 \\
- \\
-\end{array}$ & $\begin{array}{c}0.03 \\
- \\
- \\
-\end{array}$ & $\begin{array}{l}1.38(1) \\
- \\
- \\
\end{array}$ \\
\hline & & & 44 & 0.12 & 0.34 & 54 & 0.11 & 2.42 & 49 & 0.09 & 5.23 & 38 & 0.05 & 7.84 \\
\hline & \multicolumn{2}{|r|}{$\begin{array}{l}\text { The starting day } \\
\text { of the experiment }\end{array}$} & 23 & 0.09 & 0.58 & $35^{*}$ & 0.08 & 0.53 & $35^{*}$ & 0.07 & 0.51 & $25^{*}$ & 0.07 & 0.50 \\
\hline & \multirow{2}{*}{\multicolumn{2}{|c|}{ 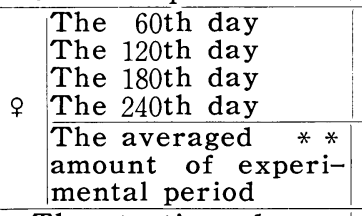 }} & $\begin{array}{l}25 \\
38 \\
38 \\
46 \\
\end{array}$ & $\begin{array}{l}0.11 \\
0.11 \\
0.12 \\
0.11 \\
\end{array}$ & $\begin{array}{l}0.52 \\
0.46 \\
0.51 \\
0.40 \\
\end{array}$ & $\begin{array}{l}55 \\
44 \\
60 \\
57 \\
\end{array}$ & $\begin{array}{l}0.08 \\
0.10 \\
0.09 \\
0.09 \\
\end{array}$ & $\begin{array}{l}\text { 3. } 17 \\
\text { 2. } 74 \\
\text { 3. } 69 \\
3.41 \\
\end{array}$ & $\begin{array}{l}35 \\
31 \\
57 \\
61 \\
\end{array}$ & $\begin{array}{l}0.06 \\
0.06 \\
0.08 \\
0.06 \\
\end{array}$ & $\begin{array}{l}4.69 \\
4.34 \\
7.65 \\
7.70 \\
\end{array}$ & $\begin{array}{r}7 \\
6 \\
5 \\
-\end{array}$ & $\begin{array}{l}0.02 \\
0.02 \\
0.01 \\
-\end{array}$ & $\begin{array}{l}2.11 \\
2.48 \\
2.04(2) \\
-\quad \\
\end{array}$ \\
\hline & & & 41 & 0.12 & 0.52 & 55 & 0.09 & 3. 45 & 51 & 0.08 & 6.84 & 39 & 0.05 & 11.28 \\
\hline \multirow{6}{*}{$\begin{array}{l}\text { The group in } \\
\text { which the } \\
\text { start of admi- } \\
\text { nistration was } \\
\text { at the early } \\
\text { part of growth } \\
\text { completion (the } \\
\text { 120th day } \\
\text { after birth) }\end{array}$} & \multicolumn{2}{|r|}{$\begin{array}{l}\text { The starting day } \\
\text { of the experiment }\end{array}$} & 36 & 0.13 & 0.38 & $47^{*}$ & 0.14 & 0.44 & $40^{*}$ & 0.13 & 0.42 & $48^{*}$ & 0.14 & 0.42 \\
\hline & \multirow{2}{*}{\multicolumn{2}{|c|}{$\delta\left|\begin{array}{l}\text { The 180th day } \\
\text { The averaged *** } \\
\text { amount of experi- } \\
\text { mental period }\end{array}\right|$}} & $\begin{array}{l}40 \\
55 \\
44\end{array}$ & $\begin{array}{l}0.12 \\
0.17 \\
0.14\end{array}$ & $\begin{array}{l}0.31 \\
0.41 \\
0.34\end{array}$ & $\begin{array}{l}57 \\
60 \\
56 \\
\end{array}$ & $\begin{array}{l}0.12 \\
0.11 \\
0.12 \\
\end{array}$ & $\begin{array}{l}2.00 \\
1.93 \\
1.84\end{array}$ & $\begin{array}{l}60 \\
62 \\
51\end{array}$ & $\begin{array}{l}0.09 \\
0.09 \\
0.10\end{array}$ & $\begin{array}{l}4.08 \\
\text { 3. } 89 \\
\text { 3. } 48\end{array}$ & $\begin{array}{r}33 \\
7 \\
6 \\
\end{array}$ & $\begin{array}{l}0.05 \\
0.04 \\
- \\
\end{array}$ & $\begin{array}{l}5.88 \\
1.81(3) \\
- \\
\end{array}$ \\
\hline & & & 43 & 0.13 & 0.33 & 56 & 0.11 & 1. 91 & 52 & 0.10 & 3. 69 & 38 & 0.07 & 5. 34 \\
\hline & \multicolumn{2}{|r|}{$\begin{array}{l}\text { The starting day } \\
\text { of the experiment }\end{array}$} & 50 & 0.13 & 0.58 & $33^{*}$ & 0.10 & 0.44 & $43^{*}$ & 0.09 & 0.42 & $39^{*}$ & 0.10 & 0.53 \\
\hline & \multicolumn{2}{|c|}{$\begin{array}{l}\text { The 60th day } \\
\text { The 120th day } \\
\text { The 180th day }\end{array}$} & $\begin{array}{l}50 \\
48 \\
50\end{array}$ & $\begin{array}{l}0.10 \\
0.10 \\
0.13 \\
\end{array}$ & $\begin{array}{l}0.40 \\
0.38 \\
0.47\end{array}$ & $\begin{array}{l}60 \\
50 \\
58\end{array}$ & $\begin{array}{l}0.07 \\
0.09 \\
0.12\end{array}$ & $\begin{array}{l}3.18 \\
2.50 \\
2.91\end{array}$ & $\begin{array}{l}60 \\
49 \\
53\end{array}$ & $\begin{array}{l}0.06 \\
0.07 \\
0.08\end{array}$ & $\begin{array}{l}6.63 \\
5.37 \\
5.62\end{array}$ & $\begin{array}{r}20 \\
8 \\
7 \\
\end{array}$ & $\begin{array}{l}0.05 \\
0.03 \\
0.02\end{array}$ & $\begin{array}{l}.94 \\
2.53 \\
2.42(4) \\
\end{array}$ \\
\hline & \multicolumn{2}{|c|}{$\begin{array}{l}\text { The averaged } \\
\text { amount of experi- } \\
\text { mental period }\end{array}$} & 47 & 0.12 & 0.47 & 53 & 0.09 & 2.82 & 53 & 0.07 & 5.78 & 35 & 0.06 & 7. 32 \\
\hline
\end{tabular}

Remarks: 1. The averaged salt intake per a rat per day for 6 days before death (died on the 96 th day) 2 . The same as above (died on the 132nd day) 3. The same as above(died on the 217 th day) 4 . The same as above (died on the $243 \mathrm{rd}$ day) $*$ The city well water intake as same with the control. ** The averaged total salt intake per a rat per day for the whole period of the experiment. 
administration. It was a notable fact that in both groups female rats lived longer than male rats.

(2) The Length of the Tail

Considering the length of the tail of both male and female control rats on the 180 th day as 100 , the authors observed the following results:

\begin{tabular}{|c|c|}
\hline LPP & $1 \%$ salt water administered \\
\hline & $2 \%$ salt water administered \\
\hline EGC & $1 \%$ salt water administered \\
\hline & $2 \%$ salt water administered \\
\hline
\end{tabular}

There was no significant difference between the sexes at the time of death caused by $3 \%$ salt water administration. The growing rate of the tail at the time of the death was as follows:

$\begin{array}{llll}\text { LPP } & \begin{array}{l}3 \\ 2.8 \%\end{array} & \text { EGC } & 30.5 \% \\ & +2.0 \% & & \$ 1.2 \%\end{array}$

The administration of salt water did not affect the growth of the tail as much as the body weight.

(3) The Amount of Calory Intake

The average calory intake per kg. per day was:

LPP

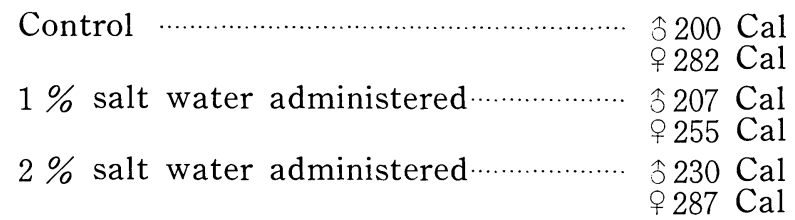

This shows that the averaged total calory intake in female per kg. per day was considerably more than in male.

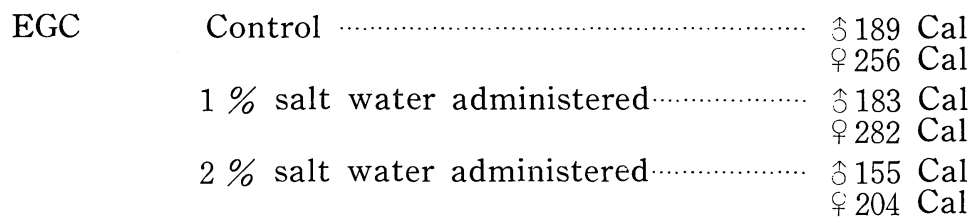

In this group, the averaged total calory intake in female per kg. per day was also more than in male. There was not a significant difference between those two groups although in the $3 \%$ salt water administered, a remarkable decrease was observed in the total calory intake per $\mathrm{kg}$. per day. The averaged total calory intake for the 6 days before the death was: LPP male $\cdots \cdots \cdot 124$ Cal, female $\cdots \cdots .90$ Cal, and EGC male ……8 Cal, female ……113 Cal.

(4) The Amount of Total Salt Intake

The averaged total salt intake per kg. per day was:
LPP
Control 


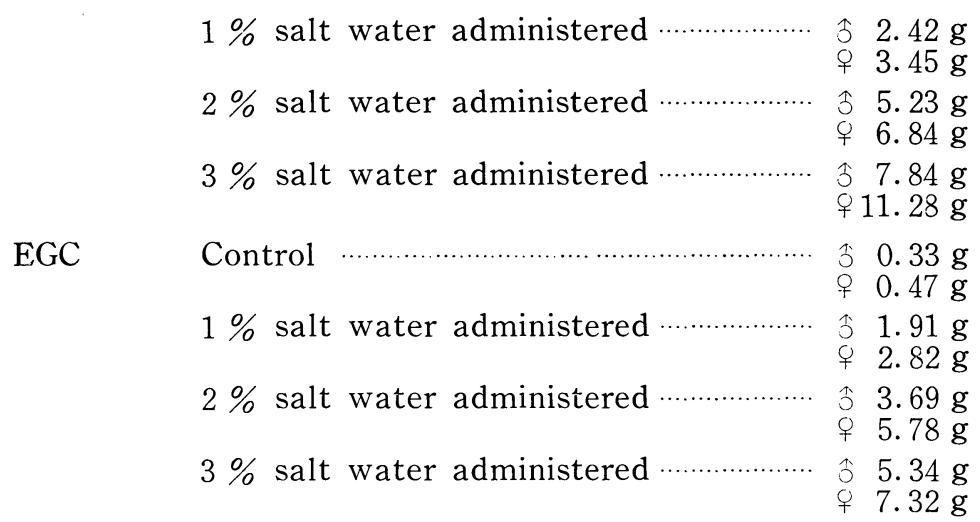

The averaged amount of total salt intake per $\mathrm{kg}$. per day was much more in LPP than in EGC, and in both groups it was interesting to note that the total amount was greater in female than male.

\section{SUMMARY}

16 rats from two litters ( 8 male and 8 female) were administered $1 \%, 2 \%$ and $3 \%$ of salt water freely, starting at the latter part of puberty (the 60th day after birth) and early part of growth completion (the 120th day after birth). The effect of salt water intake on the growth of those rats in the two different growing stages was observed.

1. The increase of body weight in the group which started taking the salt water at the latter part of puberty was inverse as the concentration increased. The growth in male was rather less than in female.

2. The increase of body weight in the group which started taking the salt water at the early part of growth completion was also inverse as the concentration increased. In comparison with the former group, however, the degree of ill effects was much less and female growth was somewhat less than male.

3. The administration of the $3 \%$ salt water caused death in all 4 rats. The period up to death was prolonged in the female about twice as in the male. Comparing the two groups, the group starting the experiment at the latter part of puberty died much earlier than the other.

4. Growth of the tail was affected relatively as the concentration increased although there was not much difference in two groups in body weight. Also there was no significant difference between the sexes.

5. Generally speaking, the averaged calory intake per $\mathrm{kg}$. per day was more in the female than the male; but the authors did not observe a meaningful difference between the two groups. The group administered $3 \%$ salt water took particularly fewer calories.

6. The total salt intake per $\mathrm{kg}$. per day was the most in the $3 \%$ salt water administered group and decreased as the concentration was lowered. The LPP group and the female sex took remarkably more salt in comparison.

The authors will make another report in the near future as to the biochemical, ecological and pathohistogical observations of the studied rats. 


\section{REFERENCES}

1. Dor,H. : The Effect of Excessive Salt on the Ascorbic Acid Content of the Blood. J. Physio. Soc. Japan, 15, 260-264, 1953.

2. Fujita, T. : Experimental Studies on the Effects of Hypoalimentation on Sexual Cycles. Igaku Kenkyu (Acta Medica), 31, 1463-1498, 1961.

3. Fukushi, S. : Fundamental Studies on Salt Intake, especially on Salt Taste, Part I-VI Hirosaki Med. J. 11, 141-167, 1960.

4. IrIe, T. : Effect of NaCl Intake upon Ascorbic Acid Metaborism. J. Physiol. Soc. Japan, 15, 570-574, 1953.

5. Kimura, T. : Excessive Salt Intake and Blood Pressure. J. Physiol. Soc. Japan, 2\%, 90-95, 1960.

6. KozAKI, S. : Experimental Arteriosclerosis by the Overdose Administration of Sodium Chloride. J. Wakayama Med. Associ., 10, 653-665, 1959.

7. Meneely, G. R., R. G. Tucker and W. J. Darby : Chronic Sodium Chloride Toxicity in the Albino Rat. I. Growth on a purified Diet containing various Levels of Sodium Chloride. J. Nutrition 48, 489, 1952.

8. Meneely, G. R., R. G. Tucker, W. J. Darby and S. H. Auerbach : Chronic Sodium Chloride Toxicity in the Albino Rat. II. Occurrence of Hypertension and of a Syndrome of Edema and Renal Failure. J. Experim. Med., 98, 71-81, 1953.

9. Mryazaki, Y. : Statistico-Epidemiological Study on the Blood Pressure of Farmers in Miyaki District, Saga Prefecture. J. Kurume Med. Associ. 24, 979-1004, 1961.

10. Okutsu, K. : Salt Hypertension in Rabbits. J. Physiol. Soc. Japan. 12, 362-367, 1950.

11. SASAKI, N. : On the geographic Distribution of salt concentration in Miso and its Relation to the Death Rate from Apoplexy in Japan. Medicine and Biology, 38, 187-190, 1956.

12. SASAKI, N. : On the geographic Distribution of Salt Intake and its Relation to the Death Rate from Apoplexy in Japan. Medicine and Biology, 44, 1-4, 1957.

13. SASAKI, N. : Studies on the Prevention of Apoplexy and Hypertension in Tohoku. Guest speech at the 17 th annual assembly of Jap. Public Health Association, Oct., 1961.

14. Sapirstein, L. A., Brandt, W. L. and Drury, D. R. : Production of Hypertension in the Rat by Substituting Hypertonic Sodium Chloride Solutions for Drinking Water. Proc. Soc. Experim. Biol. and Med., 73, 82-85, 1950.

15. Sato, T., Fukuyama, T., Urata, G. and Suzuki, T. : Studies of the Causation of Gastric Cancer. I. Bleeding in the Glandular Stomach of Mice by Feeding with Highly Salted Foods, and a Comment on Salted Foods in Japan. Bulletin Instit. Public Health Japan. 8, 10-13, 1959.

16. UKaI, J. : Fundamental Studies on Salt Intake, especially on the geographic Distribution of Salt Concentration in Miso-Soup. Hirosaki Med. J. 12, 756-765, 1961. 